\title{
Cognitive Qualities of Radio Reportage in the Light of Scientific Research
}

The world may be recorded in many wayswith sounds, a brush, but also with words ${ }^{1}$

Hanna Krall

Thus far, the problem of cognitive values which may be held by audio reportage, has not been thoroughly studied in a way that would systematize such knowledge and suggest binding and canonical solutions. It does not mean, however, that this issue has not been raised by radio experts, especially those focusing on reportage. The problem of the involvement of this genre in a cognitive process has appeared also with reference to the predecessor of audial documentary, namely the press variety of reportage ${ }^{2}$.

The cognitive function of radio reportage is listed alongside many others fulfilled by this type of medium. It affects the recipient in an informative aspect - conveying a specific portion of facts concerning e.g. an event or a person; emotional - evoking experiences that are a reaction to its contents and the emotionally marked statements of characters; aesthetic - a message composed in accordance with certain dramatic rules may provide sensations comparable to those induced by communing with art; causative - reportage has, to some extent, the ability to trigger changes in the recipient, which may result in his/her particular behaviour; and, finally, in the most important aspect from the point of view of this article - the cognitive aspect ${ }^{3}$.

\footnotetext{
* Dr, e-mail: paulina-czarnek@wp.pl; The University of Lodz, Faculty of Philology, Department of Journalism and Communication; ul. Pomorska 171/173, 90-236 Łódź.

1 J. Antczak, „Reporterka. Rozmowy z Hanną Krall”, Rosner i Wspólnicy, Warsaw 2007, p. 35.

${ }^{2}$ The following publications may be listed as examples of sources of knowledge in this field: J. Maziarski, „Anatomia reportażu”, Wydawnictwo Literackie, Cracow 1966; M. Miller, „Dziennikarstwo jako narzędzie poznania”, in: „Dziennikarstwo, media, społeczeństwo”, ed. S. Mocek, Instytut Studiów Politycznych PAN, Collegium Civitas, Warsaw 2005, pp. 31-43; K. Wolny-Zmorzyński, „Reportaż. Między literaturą a publicystyką", in: „Dziennikarstwo i świat mediów”, ed. Z. Bauer, E. Chudziński, Cracovia, Cracow 1996, pp. 173-180; K. Wolny-Zmorzyński, „Reportaż-jak go napisać?”, Fosze, Rzeszow 1995.

${ }^{3}$ This issue is raised, among others, by Kinga Klimczak (K. Klimczak, „Jak go słyszą? Studenci o reportażu radiowym. Uwagi o instytucji słuchacza", in: "Seminarium reportażu poświęcone
} 
While discussing the role of radio, Maciej Józef Kwiatkowski observed that it performs, like other media, but in its characteristic way, utilitarian tasks, simultaneously satisfying the needs of recipients.

Every individual desires to feel connected with other people, with the whole of society; wants to be informed about other people's fates, wants to receive messages that are necessary in its own, individual life; but also messages which, not being strictly utilitarian, satisfy the need for information that is characteristic of human nature ${ }^{4}$.

However, reportage is a genre which, as was previously demonstrated, may not only inform in a simple way, but also fulfill entirely different aims, including those connected with providing the necessary, from the point of view of spontaneous cognition theory, knowledge ${ }^{5}$. Kinga Klimczak, a radio reportage researcher, claims in one of her articles, albeit with a few reservations, that this genre may, to some extent, influence the cognitive process which affects every human being. Its contribution is fairly limited, though, and constitutes only a fraction of the knowledge that a person may acquire as a result of perceiving reality ${ }^{6}$.

Choosing a certain subject, the reporter takes up the task of exploring it as precisely as possible, discovering previously unknown information, shedding new light on apparently obvious facts, rendering the atmosphere of a given situation - that is conveying a certain truth about a fragment of reality? The first

prezentacji i dyskusji warsztatowej nad radiowym dokumentem artystycznym”, Kazimierz Dolny, 21-24 X 2007, pp. 85-94). A survey of views presented by many researchers with regard to the functions fulfilled by reportage may be found in Elżbieta Pleszkun-Olejniczakowa's publications, e.g. „O reportażu radiowym”, in: „Reportaż w dwudziestoleciu międzywojennym”, ed. K. Stępnik, M. Piechota, Wydawnictwo Uniwersytetu Marii Curie-Skłodowskiej, Lublin 2004, pp. 115-123.

${ }^{4}$ M.J. Kwiatkowski, ,Reporterskie formy radiowe i szkolenie reporterów i sprawozdawców radiowych”, Ośrodek Badania Opinii Publicznej i Studiów Programowych, Warsaw 1965, p. 5.

${ }^{5}$ The term "spontaneous cognition", understood as the knowledge acquired by a person as a result of ordinary interaction with reality and its creation, is analysed by Mieczysław A. Krąpiec. "In everyday life, as we survey the surrounding world, we predominantly use spontaneous cognition, in which we interiorize, that is cognitively assimilate, the contents of things we interact with. In the whole cognitive process, spontaneous cognition engages our external senses (sight, hearing, touch, taste, smell etc.) and internal senses ("common sense", which combines the sensations of individual external senses with imagination, memory and subsequently rationally-cognitive powers, which cooperate with sensual cognition, that is so-called vis cogitativa). In spontaneous cognition we capture both the fact of the existence of a thing and its essential structures through the concepts and judgements, which we immediately create and "say to ourselves" when we cognitively perceive a thing” (M.A. Krąpiec, „Epistemologia”, in: „Powszechna encyklopedia filozofii”, t. 3, ed. idem, Polskie Towarzystwo Tomasza z Akwinu, Lublin 2002, pp. 193-200).

${ }^{6}$ K. Klimczak, „Kilka uwag o semantyce dźwięku”, in: „Styl - dyskurs - media”, ed. B. Bogołębska, M. Worsowicz, Wydawnictwo Uniwersytetu Łódzkiego, Lodz 2010, p. 481.

7 "The basic purpose of this genre is to discover the truth, get to know the reality that surrounds us. It is very often bitter, painful and difficult to define. Then, the recipient is inclined to accept the 
stage of the cognitive process takes place at precisely this level, occurring in the mind of the journalist who gathers the material and studies it. Therefore, the way in which the reporter perceives and understands a given problem may significantly affect the listener's perception, which is based on the message provided by the author. Being close to the events they discuss, reporters have a chance to get to know them directly and, consequently, present them in a way that is authentic and accurate, but also, to some extent, marked by their own view of the issue.

Authenticity is the closest to the truth, since it originates from some event, deed, phenomenon, state, or situation. Authenticity, among other things, reveals subjective and fragmentary events, especially when it is expressed by a single observer, who is most frequently located in one place and at one time ${ }^{8}$.

This does not mean, however, that such a subjective touch diminishes the quality of a reportage. Entirely "clear" reception of gathered materials and accounts reaching the journalist seems impossible. Human perception is selective by nature, and language is sufficiently emotional. A sort of objectivization takes place during the process of reception and rational processing of collected information, which subsequently leads to a certain knowledge: "[...] the fact that this observer was there and registered some events according to his/her own judgements allows others to make comparisons, which enable them to learn the objective truth"'.

The message constructed by the reporter, which is a kind of communication, reaches a certain group of listeners, who absorb and interpret it in their own way. The process of perception may be affected by many elements: "[...] the connotation of the audial text's recipient also depends on his/her cultural preferences, erudite competences and - though not always to the same extent - axiological horizons"10.

These conditions should be met so that the listener may properly absorb the audial transmission, because the adequate cognition of a reportage must be based on an earlier understanding of its content. Appropriate contact must be established between the author of the reportage and the listener, and the former must use a code ${ }^{11}$ that will be properly "deciphered" by the addressee in order to fully

reporter's interpretation and draws conclusion from statements of individual characters" (M. Skarżyńska, „Reportaż radiowy w Programie 1 Polskiego Radia”, in: „Język w mediach elektronicznych”, ed. J. Podracki, E. Wolańska, Wydawnictwo Naukowe Semper, Warsaw 2008, p. 31).

${ }^{8}$ M. Kaziów, „Artystyczny reportaż radiowy. Reporter: autor i reżyser”, Kontrasty 1976, No. 3, p. 36.

${ }^{9}$ Ibid.

${ }^{10}$ E. Pleszkun-Olejniczakowa, „Od kreacji do znaczenia (Na podstawie wybranych tekstów audialnych)”, in: „O mediach i komunikacji”, ed. E. Pleszkun-Olejniczakowa, J. Bachura, M. Worsowicz, Wydawnictwo Uniwersytetu Łódzkiego, Lodz 2010, pp. 153-186.

${ }^{11}$ The relatively universal pattern created by Roman Jakobson may be used for the process of communication which takes place thanks to radio reportage. The term "code" was used here in accordance with that author's ideas (R. Jakobson, „Poetyka w świetle językoznawstwa”, in: „Współczesna teoria badań literackich za granicą. Antologia", t. 2, oprac. H. Markiewicz, Wydawnictwo Literackie, Cracow 1976, pp. 22-69). 
interpret the senses hidden in the message encountered by the recipient. Otherwise, the listener will first try to use the canons he/she knows through trial and error, and when that is not sufficient, the creator's code becomes deformed and connected with other codes, which were already available to the recipient, so that this blend combines the accidental and important, systemic, elements in the creator's language into one chaotic entirety ${ }^{12}$.

Such disturbance in the process of deciphering the sense of the message which reaches the recipient may significantly distort the cognitive process that might occur due to a valuable radio composition.

"The cognitive function is the essence of a great reportage. Cognition is, after all, something more than informing: it is -in short - a sum of information and understanding" - claims Kinga Klimczak ${ }^{13}$. It does not mean, however, that audial documentary must provide complete knowledge of a given field and answer all questions which may be asked with regard to the subject that is being discussed:

[...] most importantly, it provokes the recipients and asks them to think. The emotionality, directness and authenticity of audial texts allow the listener to enter into the atmosphere of events, become a participant for a moment and thereby understand them better ${ }^{14}$.

Stefan Polanica perceives the tasks of reportage in a similar way, drawing attention to the fact that audial messages delivered to the recipient by means of this genre consist of many elements, which should harmonize so that the programme can affect the listener in a specific way, also in the cognitive aspect.

[Reportage - P.Cz.-W.'s note] [...] is an audio image of an event or object, in which sound and descriptive elements are appropriately composed so as to make up a realistic entirety, which not only gives the recipient a suggestive impression of participating in the reported event, but also its full synthesis, its most important, mutually interdependent elements ${ }^{15}$.

The said cognition is also possible through the use of authentic sounds characteristic of a given place, situation, or event, and voices of characters, which cannot be replaced even by the best acting; it draws a phonic portrait of a character in the most accurate and authentic way. Reporters occasionally decide to apply a voice-over if a character's statements cannot be used due to objective reasons,

${ }^{12}$ E. Pleszkun-Olejniczakowa, op. cit.

${ }^{13}$ K. Klimczak, „Jak go słyszą?”, op. cit., p. 89.

${ }^{14}$ Ibid.

${ }^{15}$ St. Polanica; as cited in: Maciej Józef Kwiatkowski, op. cit., p. 16. 
as in Cezary Galek's reportage Znajdziesz mnie w szeptach traw (eng. You will find me among the whispers of grass), a story about the late journalist Tamara Zwierzyńska-Matzke.

Depending on who the character of a reportage is and what its contents are, the accompanying phonic elements complement and specify the presented reality. Sometimes they serve as an additional description of a character, a deepening of his/her thoughts, but mainly provide the reportage with the features of authentic reality ${ }^{16}$.

Let us emphasize that in an audial work of art, every element creating its sound layer carries meaning. That is why the masterful ability of forming the sound layers of a reportage, which thereby becomes a polyphonic story, are so important. "The pounding of footsteps, the sound of an ambulance passing by, or the roar of an elephant - all these phonic elements create a peculiar audioscenography; they are the carriers and creators of meanings"

The issue of the range of themes, the aspects of reality the knowledge of which reportage may expand, must also be examined. Researchers point, among other things, to the fact that it conveys important information concerning certain events from the past. According to Elżbieta Pleszkun-Olejniczakowa ${ }^{18}$, reportage, similarly to radio drama, may help to record new facts in history or fill in the so-called "white spots" in our awareness of the history of our ancestors (e.g. Janina Jankowska's reportage entitled Polski Sierpien' (eng. Polish August), which documented the events that took place in the Gdańsk Shipyard, or Anna Sekudewicz's and Marek Mierzwiak's programme Użyto broni (eng. Weapons were used) devoted to the pacification of protests in the "Wujek" mine). The knowledge conveyed by audial texts becomes even more "valuable", since it reaches the recipient in a special form, very different from that present in textbooks. This may significantly influence the chances that the cognitive process, which is obviously understood in a colloquial sense, will succeed, especially in the case of the education of children and adolescents (audial works seem to be a perfect, yet unappreciated, opportunity to improve the effectiveness of school didactics $)^{19}$.

The truths which emerge from reportage do not have to carry content of historic value, but should also - and perhaps especially - refer to the empirically experienceable "here and now", to the world surrounding the recipient. Then, this

\footnotetext{
${ }^{16}$ M. Kaziów, op. cit., p. 37.

${ }^{17}$ K. Klimczak, „Kilka uwag”, op. cit., p. 477.

${ }^{18}$ E. Pleszkun-Olejniczakowa, op. cit.

19 The issue of the role that radio reportage may play in school education was discussed by Artur Pruszyński (A. Pruszyński, „Reportaż radiowy w szkole - możliwości i korzyści”, in: „Reportaż a przemiany społeczne po 1989 roku", ed. K. Wolny-Zmorzyński, W. Furman, Wydawnictwo Wyższej Szkoły Zarządzania: Studium Dziennikarstwa Uniwersytetu Rzeszowskiego, CracowRzeszow 2005, pp. 147-155).
} 
message may provide valuable remarks concerning the image of contemporary society and thereby become a potential source of sociological knowledge: "Recognizing the problems encountered by representatives of different social groups or environments [...] will help the listener to revise his/her own position towards them, overcome reluctance, and learn toleration”20.

Such an explicit conclusion may be regarded as overly sweeping, however, it appears at least probable that this kind of message may become a stimulus for deeper reflection, which - subsequently - might contribute to certain revaluations ${ }^{21}$.

The reasons why reportage exerts such a strong influence should be sought in the fact that this genre, relies on a natural dramatic tension of events, and enriches it with a tremendous emotional charge which moves the recipient. The feelings of characters are conveyed mostly through their voice - the listener cannot see their reactions, however, applying the knowledge gathered during everyday functioning in the world, can vividly imagine the real appearance of these events. Therefore, in some respects, the character of a reportage will always remain anonymous. Undoubtedly, audial documentary makes it possible to take a closer look at a certain individual and get to know his/her changing fortunes. Thanks to that, the recipient may establish a unique relationship with a person whom, perhaps, he/she would never encounter in the outside world. This meeting takes place in special conditions, is based on a unilateral contact, and it is difficult to talk about feedback (in an exceptional situation the listener may meet the characters of a reportage and talk to them personally, as in the case of Mrs. Danuta Radzka from Katarzyna Michalak's programme entitled Niebieski płaszczyk (eng. Blue coat), who participated in the author's evening that took place in Warsaw as part of "Encounters with reportage" organized by Irena Piłatowska in Klub Księgarza). Such ostensible, mediated contact is, however, a chance for an in-depth reflection, because the recipient does not have to react ad hoc to what a character says, but may calmly ponder various issues. Audio experiences obtained due to the reception of a radio transmission are also translated into images, which results from "verbo-motor activity"22 of the radio as a medium, and in consequence of this iconization they reach the collective social consciousness.

\footnotetext{
${ }^{20}$ Ibid., p. 151.

${ }^{21}$ This view may also be found in Kinga Klimczak's numerous articles, including: „Funkcje i odbiór reportażu radiowego (na przykładzie wybranej grupy studentów UŁ). Kilka uwag o instytucji słuchacza”, Media - Społeczeństwo - Kultura. Zeszyty Naukowe Wyższej Szkoły Dziennikarstwa im. Melchiora Wańkowicza w Warszawie 2009, No. 1, pp. 55-65.

${ }^{22}$ This concept, coined by Walter Jackson Ong, is used in accordance with: M. Steciąg, „Informacja, wywiad, felieton. Sposób istnienia tradycyjnych gatunków w radiu komercyjnym”, Uniwersytet Zielonogórski, Zielona Góra 2006, pp. 61-62.
} 
Identifying with a character in a reportage, a real person - though represented only by voice - is different from co-experiencing events with a literary or film character, because mostly it is the action that is in the foreground of a novel or a film. In radio - especially in programmes in which characters are speaking - the events are dominated by the reactions of characters, which are usually based on reflection. The recipient participates in this reflection as well ${ }^{23}$.

Hence, the listener has a chance not only to become familiar with a certain fragment of reality, the people living in it, and emotions that accompany them, but also to learn something about him/herself on that basis.

A reportage aspiring to be recognized as an audial work of art, like other outstanding artistic creations, gives an opportunity to touch a certain mystery that accompanies our functioning in the world, which is often the source of human searching and pursuits aimed at discovering the sense and secrets of our existence. Therefore, the contribution of radio reportage to the cognitive process may be compared, for instance, to that occurring through literary, artistic or musical works. This property, admittedly with reference to the described variety of reportage, has also been discussed by, among others, the creators of Reportage Laboratory; as it seems, this statement may be successfully applied to descriptions of audial texts:

Journalism is an art, and reportage is its richest and deepest emanation [...] Reportage is a tool for building the world, a cognitive tool, a vehicle for studying the surrounding reality, which is a mystery ${ }^{24}$.

Hence, the cognitive process which takes place as a result of interacting with works of audial art proceeds in an entirely different way from scientific cognition based on a logical, analytical argument. In radio reportage, the listener encounters an authentic story told in a polyphonic, mosaic manner, which synthetically presents a certain fragment of reality. The knowledge provided by this genre is also significantly different from the strictly scientific. It should not be perceived in terms of innovation, but sought for utilitarian qualities. Reportage may effectively popularize essential information, acquaint a wider audience with events they may not necessarily be close to. It fills a specific informational gap: for example, Cezary Galek's Rok czarnego stońca (eng. The year of the black sun) conveys considerable knowledge on the subject of the tragedy in Beslan, whereas Magdalena Skawińska's Libacja (eng. Carousal) unveils the mysteries of an allegedly provocative alcoholic carousal in the editorial office of the Przyjaciótka

${ }^{23}$ A. Pruszyński, op. cit., p. 152.

${ }^{24}$ Laboratorium Reportażu, „Idea”, http://www.e-fotowarsztat.pl/o_nas/idea [access: 30.09.2010]. 
periodical, which was notorious in post-war Poland. The effects of reportage may be compared to those of popular science literature, which provides valuable and educational information in an accessible way.

In the context of views of radio documentary researchers presented in this article, it is justifiable to claim that reportage is capable of being a source of substantial knowledge. This depends on many conditions, which depend on both the way the audial matter is organized and the perceptual abilities of the recipient. It seems that the potential of radio reportage is worth studying, as it may lead to the gathering and systematizing of knowledge of the ways in which particular realizations of this genre "record the world".

\section{Bibliography}

Antczak J., „Reporterka. Rozmowy z Hanną Krall”, Rosner i Wspólnicy, Warsaw 2007.

Jakobson R., „Poetyka w świetle językoznawstwa”, in: „Współczesna teoria badań literackich za granicą. Antologia”, t. 2, oprac. H. Markiewicz, Wydawnictwo Literackie, Cracow 1976, pp. 22-69.

Kaziów M., „Artystyczny reportaż radiowy. Reporter: autor i reżyser”, Kontrasty” 1976, No. 3, p. 36.

Klimczak K., „Funkcje i odbiór reportażu radiowego (na przykładzie wybranej grupy studentów UŁ). Kilka uwag o instytucji słuchacza", Media - Społeczeństwo - Kultura. Zeszyty Naukowe Wyższej Szkoły Dziennikarstwa im. Melchiora Wańkowicza w Warszawie 2009, No. 1, pp. 55-65.

Klimczak K., „Jak go słyszą? Studenci o reportażu radiowym. Uwagi o instytucji słuchacza”, Acta Universitatis Lodziensis. Folia Litteraria Polonica 2008, No.11, pp. 287-299.

Klimczak K., „Kilka uwag o semantyce dźwięku”, in: „Styl - dyskurs - media”, ed. B. Bogołębska, M. Worsowicz, Wydawnictwo Uniwersytetu Łódzkiego, Lodz 2010, pp. 471-484.

Klimczak K., „O estetyce i etyce w reportażach Janiny Jankowskiej”, in: „Media Studies. Refleksja nad stanem obecnym”, ed. K. Stępnik, M. Rajewski, Wydawnictwo Uniwersytetu Marii Curie-Skłodowskiej, Lublin 2008, pp. 377-384.

Krąpiec M.A., „Epistemologia”, in: „Powszechna encyklopedia filozofii”, t. 3, ed. idem, Polskie Towarzystwo Tomasza z Akwinu, Lublin 2002, pp. 193-200.

Kwiatkowski M.J., „Reporterskie formy radiowe i szkolenie reporterów i sprawozdawców radiowych”, Ośrodek Badania Opinii Publicznej i Studiów Programowych, Warsaw 1965.

Laboratorium Reportażu, „Idea”, http://www.e-fotowarsztat.pl/o_nas/idea [access: 30.09.2010].

Maziarski J., „Anatomia reportażu”, Wydawnictwo Literackie, Cracow 1966.

Miller M., „Dziennikarstwo jako narzędzie poznania”, in: „Dziennikarstwo, media, społeczeństwo”, ed. S. Mocek, Instytut Studiów Politycznych PAN, Collegium Civitas, Warsaw 2005, pp. 31-43.

Pleszkun-Olejniczakowa E., „Od kreacji do znaczenia (Na podstawie wybranych tekstów audialnych)”, in: „O mediach i komunikacji”, ed. E. Pleszkun-Olejniczakowa, J. Bachury, M. Worsowicz, Wydawnictwo Uniwersytetu Łódzkiego, Lodz 2010, pp. 153-186.

Pleszkun-Olejniczakowa E., „O reportażu radiowym”, in: „Reportaż w dwudziestoleciu międzywojennym”, ed. K. Stępnik, M. Piechota, Wydawnictwo Uniwersytetu Marii Curie-Skłodowskiej, Lublin 2004, pp. 115-123. 
Pruszyński A., „Reportaż radiowy w szkole - możliwości i korzyści”, in: „Reportaż a przemiany społeczne po 1989 roku”, ed. K. Wolny-Zmorzyński, W. Furman, Wydawnictwo Wyższej Szkoły Zarządzania: Studium Dziennikarstwa Uniwersytetu Rzeszowskiego, CracowRzeszow 2005, pp. 147-155.

Skarżyńska M., „Reportaż radiowy w Programie 1 Polskiego Radia”, in: „Język w mediach elektronicznych", ed. J. Podracki, E. Wolańska, Wydawnictwo Naukowe Semper, Warsaw 2008, pp. 27-38.

Steciąg M., „Informacja, wywiad, felieton. Sposób istnienia tradycyjnych gatunków w radiu komercyjnym", Uniwersytet Zielonogórski, Zielona Góra 2006.

Wolny-Zmorzyński K., „Reportaż — jak go napisać?”, Fosze, Rzeszow 1995.

Wolny-Zmorzyński K., „Reportaż. Między literaturą a publicystyką”, in: „Dziennikarstwo i świat mediów", ed. Z. Bauer, E. Chudziński, Cracovia, Cracow 1996, pp. 173-180.

Paulina Czarnek-Wnuk

\section{Cognitive Qualities of Radio Reportage in the Light of Scientific Research}

\section{(Summary)}

Despite the fact that radio documentaries broadcast mainly strong emotions, the news value of this genre is also an essential feature. Therefore, it is necessary to describe the potential of such works to expand knowledge about the surrounding world which could be significant for the listeners. The aim of this article is to present theses put forward by scholars with regard to radio documentaries. Researchers' analyses are related to the genre's potential to broaden people's minds and influence the recipient's perception.

Keywords: cognitive qualities, radio broadcasting, radio reportage. 